\title{
Agro-Environmental Education in the Pedagogical School
}

\author{
Franciss Brown Smith \\ University of Pedagogical Sciences Enrique José Varona
}

\author{
Amparo Osorio Abad \\ University of Pedagogical Sciences Enrique José Varona \\ Enrique Cecilio Cejas Yanes \\ University of Pedagogical Sciences Enrique José Varona
}

\begin{abstract}
Agri-environmental education is one approach to achieving sustainable development. Agri-environmental activities are designed at the national, regional or local level, so that they can be adapted to different farming systems and environmental conditions. From an educational and training point of view, this approach is used in pedagogical school as an environmental education tool. The aim of this paper is to systematize the theoretical foundations of agro-environmental education in the pedagogical school and to contribute to the comprehensive education of students. The theoretical systematization of the foundations of agro-environmental education in pedagogical school and its importance is presented as a result. Systematization, document analysis, and literature review were used, which made it possible to consult theses. The theoretical systematization carried out constitutes the basis for the argumentation of the different positions in relation to agro-environmental policies, environmental problems and the need for environmental education, as well as the contents that should be addressed in this sense in the preparation of teachers and students as centers for the implementation of agro-environmental activities.
\end{abstract}

Keywords: sustainable, development, dimension, environment

\section{INTRODUCTION}

Increasing the quality of education is one of the main objectives of the education system. In this sense, it is considered that it is necessary to "continue advancing in improving the quality and strictness of the teaching-educational process, as well as to give hierarchy to the training of teachers ... (Guideline 117 of the economic and social policy, 2012).

In the same vein, the position of some researchers, such as Álvarez (1996); Álvarez (2004); Addine (2004); García (2004); Caballero (2004) and Chávez (2005), among others, who highlight the need to increase the quality of education and the improvement of the teaching staff in order to achieve the integral training of the new generations in accordance with the demands of the current Cuban society where the complex challenges of the economic, political and social crisis, with serious effects on the environment, are being faced. 
Environmental problems persist as one of the major political, economic, social and educational concerns of contemporary world society. That is the reason why environmental protection and the conception of sustainable development require wills, decisions and the implementation of political, economic, scientific, technical and educational actions, among other elements highlighted by Valdés (Valdés, 1995) in his $\mathrm{PhD}$ thesis.

In this connection, researching teachers express concern and warn regarding the need for environmental education as a solution to the different environmental problems that arise in educational institutions and their context. At the international level the following authors can be mentioned: Novo (1998); Leff (1998); Moreno (2005); Castelltort (2007) Sammarco (2014); Varela (2016) and at the national level: Valdés (1995); Díaz (2001); Santos (2002); Bosque (2002); Roque (2003); McPherson (2004); Amador (2008); Osorio (2012); Feijoo (2016), among others.

Researchers who have provided interesting scientific results in line with current demands regarding the systematization of environmental education in its different expressions, such as: methodological strategies, conceptions, methodologies that favor the development of environmental knowledge and attitudes.

In the same vein, it is necessary to give priority consideration to the environmental education of educational practitioners, based on the development of a system of knowledge, skills and attitudes, which allow the implementation of a professional mode of action, in correspondence with the environmental educational demands in each educational scenario.

Taking into consideration the performed analysis, it has been possible to confirm the need to continue systematizing the theoretical foundations related to environmental education and the prioritized environmental problems that represent knowledge that teachers and students should have. For this reason, the teacher training school should assume this knowledge in a way that reflects the problems of the educational institution and its context, and in this sense it is considered a tool to integrate contents and to develop them in accordance with the current demands of environmental education focused on sustainable development, which is required by the country's policy and the development model to which it aspires, so the systematization proposal and its considerations are relevant. Therefore, it is suggested as an objective to systematize the theoretical foundations of agro-environmental education in the teacher training school that contributes to the integral training of students and the agro-environmental pedagogical preparation of teachers for sustainable development.

\section{MATERIALS AND METHODS}

The integral training of the teacher and the student in the teacher training school is becoming more and more necessary and essential, taking into account that the teacher trained in these schools will play his or her professional pedagogical role in the other education subsystems and is the source of direct admission to the University of Pedagogical Sciences. It is therefore important that this middle-level pedagogical training be as comprehensive as possible, in accordance with the social needs of the country in which it is provided.

In this scientific and educational research we used literature review and documentary analysis for the study and analysis of $\mathrm{PhD}$ theses, master's degrees, research project reports, scientific articles from countries such as Brazil, Colombia, Mexico, Chile, Nicaragua and Cuba, guiding documents such as the Guidelines for Economic and Social Policy, 2016-2021, National Environmental Education Program for Sustainable Development, 2017, The 2030 Agenda and Sustainable Development Goals, 2015, statements, policies and agreements taken in meetings such as, the XX Forum of Ministers of Environment of Latin America and the Caribbean, 2016 and the FAO Regional Office for Latin America and the Caribbean, UN, 2014 that allowed obtaining an integrated conception of the subject in relation to the environment and environmental education. The analysis-synthesis made it feasible to specify the areas of environmental knowledge to be addressed in the research as prioritized contents, and also as a procedure in the analysis of the literature reviewed and its synthesis. Theoretical systematization for the study of different authors, which influenced the organization of scientific knowledge with a view to the solution of the problem posed. 
It made it possible to provide a detailed basis for the described problems, as well as to systematize the agroenvironmental approach in the research.

\section{RESULTS AND ANALYSIS}

In order to understand agro-environmental education as part of the integral training of students in teacher training schools, the analysis of the concepts of environment and environmental education, sustainable development and their relationships will be used as a basis for the knowledge of the foundations of this approach for the educational system.

In the study performed, definitions of environment have been analyzed, from some authors such as: Delors, (1996), Novo (1998), Roque(2003), McPherson Sayú, (2004) and highlighting those offered by Law 81(1997) and the National Environmental Strategy (1997, 2016-2020) where it is stated that environment: "System of abiotic, biotic and socioeconomic elements with which humans interact, while adapting to it, transforming it and using it to meet their needs" (Law 81/1997).

According to the National Environmental Strategy approved in 1997, the environment is defined as a complex and dynamic system of ecological, socioeconomic, and cultural interrelationships that evolves through the historical process of society. This definition approaches the environment with a procedural and historical perspective, in addition to incorporating the most essential elements (the natural ones and the most important elements of society, the economic system and culture), a definition assumed by the author.

The definition of the environment considers the existence of different subsystems where, within the economic subsystem, the agricultural system is one of its components, establishing different relationships such as: nature-nature type relationships, nature-society type relationships and society-nature type relationships.

For the period (2010-2015, 2016-2020), the National Environmental Strategy states that Cuba's main environmental problems include soil degradation, vegetation damage, pollution, loss of biological diversity, lack of water, climate change, among others.

In the study performed, it was possible to analyze that the principal problems of environmental degradation are determined by lifestyles and behavioral models arising from the dynamic evolution of environmentally unfriendly economic systems and their relationships depending on their characteristics. Therefore, its solution is not so much to act on the environment, but on the human activities through which the relationship with it is maintained, based on knowledge, changes in values, in social coexistence and in the fair conception and application of human solidarity, with a new ethic, all of which implies a new paradigm of development, based on sustainability.

The influence produced by significant international and national events related to environmental deterioration led to the emergence of an environmental education concept with a conservationist approach in the 1970s, which then moved towards a concept of environmental protection during the 1980s, going through a strategic approach, until transcending from the 1990s to a concept of environmental education for sustainable development up to the present day, where authors such as: (Colom and Sureda, 1989); (Novo, 1998,2006); (Valdés, 1995); (Santos, 2002); (Roque, 2003); (McPherson, 2004); have made their contributions in this sense.

In the same vein, the issue of environmental conservation is considered of utmost importance and has multiple ways to address it. That space where life and its natural components develop, is being rapidly modified by human activities and represents a priority for the 2030 Agenda in which reference is made to ensuring education for sustainable development in which "learners undertake responsible actions for the integrity of the environment". (UNESCO, 2015, p. 30).

This research addresses environmental education as a curricular strategy or transversal, multidisciplinary and transdisciplinary axis used in schools in order to develop awareness in the educational community, integrating knowledge and attitudes reflected in behaviors, taking into consideration that environmental education seeks responsible behavior, knowledge about the environment and its problems.

When analyzing the different definitions, the concept of environmental education proposed by Law 81 of the Environment (1997) is emphasized and assumed, which defines environmental education as "a 
continuous and permanent process that constitutes a dimension of the integral education of all citizens, focused on the acquisition of knowledge, the development of habits, skills, abilities and attitudes, and the creation of values to harmonize the relationships among human beings and between them and the rest of society and nature, in order to promote the direction of economic, social and cultural processes towards sustainable development."

It is in agreement with Herrera, Y. R., \& Valdés, Y. D. when stating that the above definition constitutes a starting point for the Cuban environmental policy which considers environmental education as a guiding axis of sustainability, thus assuming that environmental protection is a priority to ensure economic and social development, health and survival of the human species throughout the planet; hence the need to include teaching-learning models that contain an environmental dimension with an interdisciplinary approach as proposed by Valdés, Rodríguez, Llivina, and Merino (2012) and Valdés (2019).

The author of this research highlights the problems of soil, water, biodiversity, climate change and their management through environmental education in school agricultural ecosystems. In general, environmental education is considered to be a tool for people to become aware about the importance of preserving their environment, agricultural ecosystems as a source of food for the survival of different species, promoting a change in their thoughts and actions with environmentally friendly behaviors, values and lifestyles, as well as expanding their knowledge to encourage them to take action through prevention and mitigation of existing problems.

Cuba is among the states that must work hardest to face these environmental challenges given its status as an archipelago, where the effects of climate change are already evident in the behavior of meteorological variables due to the frequency and intensity of natural disasters linked to them, with significant impacts in several territories of the country and especially, as stated in the National Environmental Strategy, in the coastal zone and in the socio-economic activities that take place there, among which the agricultural ecosystem and food production stand out, as a matter of national security in the country.

It also takes into consideration elements of agroecology as a scientific discipline that allows for a more holistic understanding of agricultural problems by approaching the study of agriculture from an ecological perspective, which goes beyond a one-dimensional view of agricultural ecosystems and incorporates the approach of agriculture more closely linked to the environment, focusing not only on production but also on ecological sustainability.

Agroecology combines ideas and methods of agriculture, and has its roots in the agricultural sciences, in the environmental protection movement, in ecology, in the analysis of native agroecosystems and in studies concerning rural development (Altieri, 1995). It can be considered the scientific basis of the methods used in the agricultural production system, since they all pursue a common objective: "the sustainability of the agroecosystem in its relationship with human communities"(Altieri, 1995).

A strategic factor of change is knowledge management, as a process of transformation towards sustainability. (Ojeda, 2002, 2008). I agree with the author regarding her evaluation, taking into account that scientific knowledge is the basis for the development of all social systems and is essential during the development of educational processes. In this research, the preparation of teachers in teacher training schools is materialized in the acquisition of knowledge related to the environment and environmental education by promoting agro-environmental activities in the school context, hence its importance for this research.

In this sense, the author considers that the expression of knowledge about the environment and agroenvironmental activities in research is evidenced in the preparation in environmental education that the teacher of a teacher training school must have in order to incorporate it and transmit it to his or her students in training.

In this same vein, the country adopts the State Plan for the confrontation of Climate Change the "Task Life" (2017) where 5 strategic actions and 11 tasks are established. The Ministry of Education will focus its actions on tasks related to school contents and the organic part of the methodological preparation of teachers, their classroom approach and the current work of the Improvement of the National Education System. 
Among the prioritized lines or strategic actions are related to adapting agricultural activities, particularly those with the greatest impact on the country's food security, to changes in land use as a consequence of sea level rise and drought, and reducing crop areas close to the coasts or affected by saline intrusion. To diversify crops, improve soil conditions, introduce and develop varieties resistant to the new temperature scenario.

In the theoretical systematization that was carried out, it became evident that sustainable development is necessary in all actions that are planned. This development declares three dimensions (economic, environmental and social), that is why its approach is three-dimensional, and was stated by Brundtland, the environmentalist who chaired the commission that signed the report called: Our Common Future. This document offered significant results worldwide, because it consolidated and reaffirmed the concepts and criteria on: interdependence of the environment with economic and social development; the need to achieve sustainable development; and the degradation and irrational exploitation of the environment. This approach is considered by many authors to be multi-causal since there are other dimensions such as ethical, cultural and historical, technological and measurable in a given period of time.

In the same vein (Valdés,1996) states that the procedures must consider and involve a real and objective evaluation of the cost and benefit of all agricultural, economic, industrial and social development programs and projects, in terms of their impact and demand on environmental resources, the ecological balance and the quality of the environment, in general, for present and future generations, he also states that the achievement of sustainable development depends on the priority and political, economic and social will given to environmental protection, together with the scientific, technical and legal activities and the environmental education work carried out by schools and other governmental and non-governmental organizations of a state, considerations that I fully share taking into consideration "that development is a social condition in which the authentic needs of its population are satisfied with the rational and sustainable use of resources and natural systems ... is that process of transformation of the natural environment into an artificial constructed environment, by the interaction of four elements: technology, energy, social organization and culture" (Dictionary of Geographical Terms, 2012) in this sense the strategy implemented from the Guidelines of the Economic and Social Policy in Cuba and the role played by the educational system is taken into account.

In a general way, sustainable development is assumed as: "process in which economic, fiscal, trade, energy, agricultural and industrial policies are designed with the purpose of achieving development that is economically, socially and ecologically sustainable, that is, that meets the needs of current generations without limiting the potential for the satisfaction of future generations, is declared as a synonym of sustainable development" (Dictionary of Geographical Terms, 2012) however sustainable development as stated by The United Nations World Commission on Environment and Development, commonly known as the Brundtland Commission, established in 1987, the concept of sustainable development, which is derived from the Latin, sustinere, meaning to maintain in existence, implying permanence or long-term support (Rigby and Cáceres, 2001). Therefore, its definition states that "it is a development that meets the needs of current generations without compromising the ability of future generations to meet their own needs"( Brundtland,1987) .This concept has several dimensions: physical, ecological, social, cultural and ethical, and is based on the principle of intergenerational equity, which stipulates that future generations should not inherit the burden of avoidable environmental problems. In other words, the objective is to improve the quality of life of mankind and, at the same time, to live within the maximum admissible capacity of the ecosystems, since it is recognized that development is a process aimed at improving the living conditions of the population and, at the same time, recognizing that the capacity of the environment is limited (Martens et al., 1998). In this sense, I consider that this definition and that of sustainable development pursue the same objective and contain the same dimensions.

The drive towards the implementation of sustainable agriculture is important because it is widely recognized that food production produces effects on the environment or the economy that are not reflected in the cost of food. Agricultural sustainability takes place in production systems that make the best use of nature's goods and services while not causing damage to the environment. In order to achieve sustainability, 
it is necessary to promote the integration of natural processes such as nutrient cycling, nitrogen fixation, soil regeneration and the management of natural enemies of pests into food production processes.

The author of this research shares the view that Sustainable Agriculture "comprises a system of interacting and interconnected socioeconomic, scientific-technical, cultural and educational actions" (Dictionary of Geographical Terms, 2012), with the objective of the conservation and rational use of natural resources, the decontamination of the environment, the increase of agricultural yields and productivity. Technologies, techniques and resources are adapted to specific ecosystems, reducing the consumption of external resources and ensuring the satisfaction of existing needs without compromising those of future generations (Dictionary of Geographical Terms, 2012).

Similarly, sustainable development is adapted to the local contexts of these three areas, and takes many different forms around the world. The ideals and principles that comprise sustainability include broad concepts such as gender equity, intergenerational equity, peace equity, tolerance, poverty reduction, environmental preservation and restoration, conservation of natural resources, and social justice (UN, 2012). According to this universally adopted approach to sustainable development, sustainable agriculture is based on three pillars. The economic dimension: profitable production, the environmental dimension: protected environment and the social dimension: prosperous communities (United Nations Organization UN, 2012).

In order to impose this need to incorporate the three most essential pillars, it is necessary to structure, implement and evaluate environmental education strategies with a sustainable approach, since it is essential to create an environmental education that promotes the teaching about nature by using it as an educational resource. For consistency with the definitions of the basic concepts expressed above, which recognize the use of agri-environmental policy: understood this public policy as a principle, guide or a plan of action of a government, institution or social group, which is executed through a set of programs, laws, regulations, projects and actions (UN, 2014). The objectives are inserted and proposed in accordance with the principles of the three dimensions of sustainable development: social, economic and environmental.

There are different conceptions of the principles that should guide agri-environmental policies. Similarly, there is a large variety of contexts and spatial and temporal scales in which agri-environmental programs have been implemented. Agri-environmental activities are designed at the national, regional or local level, so that they can be adapted to different farming systems and environmental conditions. Agrienvironmental activities can be categorized according to two broad objectives: reduction of environmental risks associated with modern agriculture; and preservation of nature and agricultural landscapes. Agrienvironmental activities are also often classified according to the type of agricultural land (productive or unproductive) at which they are targeted. Organic agriculture, crop rotation, minimum tillage, planting cover crops, protection of agrodiversity and measures for the efficient protection of water and soil through organic matter are agricultural activities grouped under agri-environmental activities for productive lands and for unproductive lands, among others: favoring the conservation of water, soil and biodiversity, preventing fires and controlling erosion, preservation of the natural landscape, among others. "Another proposed definition indicates that the agro-environmental concept" refers to a cross-sectoral approach that promotes the sustainable use of economic space; through production and conservation systems that improve economic competitiveness, human welfare and the sustainable management of land and its natural resources, in accordance with the socioeconomic processes occurring in the territory" (Moreira and Bianco, 2005).

The author concludes that agri-environmental policies can also be strategies for environmental education, considering the school agricultural ecosystem as an educational resource. The school agricultural ecosystem is defined as a "dynamic complex of plant, animal, fungal and microorganism communities and the non-living environment linked to it, which makes it an ecological unit" (Dictionary of Geographical Terms 2012, ecology being understood as "biological science that studies the interaction and interrelationship of organisms and communities with the natural environment and the influence of the latter on them" (Dictionary of Geographical Terms 2012).

The author considers that the school agricultural ecosystem can be identified by the school garden or cook's garden, the school organoponic garden where medicinal and condiment plants are sown, propagated 
and reproduced, the Marti garden, the ornamental plant garden, areas around the school which, due to their characteristics and soil properties, are used for urban, suburban and family agriculture, as well as for planting fruit or timber trees. These areas offer, due to the integrity and diversity of abiotic, biotic and socioeconomic components, extraordinary advantages and possibilities for the development of environmental education in schools. The author concludes that these activities that take place in these agricultural ecosystems during environmental education activities are called and assumed to be agrienvironmental activities.

For this reason, from the educational point of view and for this research, the author considers as agroenvironmental activities: "All those activities focused on the conservation and improvement of the school agricultural ecosystem and its environment during the process of environmental education oriented to sustainable development" (Brown, 2020). I consider that this proposal provides an answer to the implementation of agro-environmental policies from the educational system in Cuba, specifically in the Pedagogical school (Brown, 2020).

Considerations that allow us to value the importance of agro-environmental education as: the process through which teachers and students acquire the required knowledge for the development of agricultural activities from a sustainable development perspective through agro-environmental pedagogical preparation (Brown, 2020), which requires that these activities be carried out under conditions of sustainability. At the same time, an integral agro-environmental education and training should be promoted and favored in the teacher training school, which will allow the efficient management of the teaching process by integrating agricultural and environmental contents.

\section{CONCLUSIONS}

The theoretical systematization carried out represents the foundation and it is of vital importance for this research since it argues the different positions in relation to the problem of the environment and environmental education, its priorities as well as the knowledge that should be addressed on environmental education in the preparation of teachers and students in the context where it is the center in the execution of agro-environmental activities, particularly in the teacher training school.

The environmental crisis represented by food production requires a scientific analysis of the societynature conflict, since there is no sustainable development model that does not take into consideration the human-environment link. Starting from this basic premise, it will be possible to move from an evaluation and addressing of environmental problems to preventive policies that systematically integrate environment and development.

Environmental education focused on sustainable development involves managing the present and the future of the agricultural environment. In this sense, the need to implement agri-environmental policies that promote the conservation and preservation of natural resources associated with school agricultural ecosystems and the agri-environmental activities that take place in them becomes relevant.

\section{ACKNOWLEDGEMENT}

Translated \& edited by American Publishing Services (https://americanpublishingservices.com/).

\section{REFERENCES}

Addine Fernández, F. (2004). Didáctica teoría y práctica. La Habana, Editorial Pueblo y Educación.

Altieri, M.A. (1995). Agroecología. Bases científicas para una Agricultura Sostenible (3.ra edición). S.1., s.n.

Álvarez de Zayas, C.M. (1996). Hacia una escuela de excelencia. La Habana: Editorial Pueblo y

Educación

Álvarez de Zayas, C.M. (2004). La interdisciplinariedad, en la enseñanza - aprendizaje de las ciencias. Compilación. La Habana: Editorial Pueblo y Educación. 
Amador, E.L. (2008). Estrategia metodológica para integrar la educación ambiental en la formación permanente del profesor general integral habilitado de secundaría básica. _ 2008._ $120 \mathrm{~h}$. (Tesis de Doctorado). ISP "Rubén Martínez Villena", La Habana.

Bosque, R. (2002). La excursión docente en la Educación Primaria: Una propuesta para el perfeccionamiento de su realización. _ 2002. _ 120 h. (Tesis de Doctorado). ISP Enrique J. Varona, La Habana

Brown, F. (2020). La educación ambiental como herramienta para el desarrollo sostenible en la escuela pedagógica. Manuscrito presentado para su publicación.

Brundland et al. (1988). Nuestro Futuro Común. Madrid: Alianza.

Castelltort. (2007). La educación ambiental. Madrid, España.

Colom, A. (1989). Socially responsible management of thermal environment, especially hot environment. Estados Unidos: Editorial Quality.

Colom, A., \& Sureda, J. (1989). Questions on the composition and quality of end-product in the process of pyrolytic waste processing. Retrieved from http://www.Unescodoc.unesco.org/images

Delors, J. (1996). La Educación encierra un tesoro. Informe a la UNESCO de la Comisión Internacional sobre la Educación para el siglo XXI. Madrid, UNESCO.

Díaz, R. (2001). Educación ambiental y desarrollo sostenible. Estrategia didáctica. ISP "Pepito Tey", Las Tunas.

Estrategia Ambiental Nacional. (1996). CITMA, La Habana, Cuba

Estrategia Ambiental Nacional. (2016-2020). CITMA, La Habana, Cuba

Feijoo, M.E. (2016). Estrategia pedagógica para la formación ambiental en las especialidades técnicas de la Licenciatura en Educación. [Tesis doctoral], UCPEJV, La Habana. 2016.

García, G., \& Caballero, E. (2004). Profesionalidad y práctica pedagógica. La Habana, Pueblo y Educación.

Herrera, Y.R., \& Valdes, Y.D. (2020). La lectura de textos digitales que contribuyan a la educación ambiental. Revista Brasileira de Educação Do Campo, 5, 1-24. https://doi.org/10.20873/uft.rbec.e6770

Leff, E. (1998). Formación ambiental: Saber/racionalidad/poder. Siglo XXI, CIICM UNAM/PNUMA.

Ley de medio ambiente. (1997). Asamblea Nacional. Gaceta Oficial de Cuba.

Lineamientos de la Política Económica y Social del Partido y la Revolución. (2012). VII Congreso del PCC. La Habana, Cuba

Lineamientos de la Política Económica y Social del Partido y la Revolución. (2016-2021). VII Congreso del PCC. La Habana, Cuba

Llivina, M. (2012). Conferencia sobre el Decenio de la Educación para el Desarrollo Sostenible. XVII Taller de Gestión de la Educación Ambiental. UCP E.J.V. Ciudad Libertad. La Habana. 2012.

Martens, P., \& others. (1998). Health and Climate Change. (Environment and Health Series). Editorial Routledge

McPherson Sayú, M. (2004). Medio Ambiente, Desarrollo Sostenible y Educación Ambiental en la Formación de Docentes. La Habana, Editorial, Pueblo y Educación.

Moreira, A., \& Bianco, E. (2005). Inventario de Políticas Agroambientales en Uruguay. Montevideo, Uruguay. IICA / Agriculture and Agri-Food Canadá.

Moreno A., Reyes J.L., \& Márquez, C. (2015). Tópicos Selectos de Sustentabilidad: Un Reto

Permanente. Volumen III. En El desarrollo y la agricultura sustentable (pp. 65-66). Editorial de la Universidad Juárez del Estado de Durango.

Moreno, E. (2005). La formación inicial en educación ambiental de los profesores de secundaria en periodo formativo. _ 2005, [296] h. __ (Tesis de Doctorado). Universidad de Valencia, España

Novo, M. (1998). La Educación ambiental: bases éticas, conceptuales y metodológicas. Madrid.

Novo, M. (2006). El desarrollo sostenible. Su dimensión ambiental y educativa. S.A., Madrid: UNESCOPearson.

30 Journal of Strategic Innovation and Sustainability Vol. 17(1) 2022 
Ojeda, R. (2002). Sistema de información y conocimientos para el desarrollo agrario y rural. Centro de Estudios de Desarrollo Agrario y Rural. Universidad Agraria de La Habana, Cuba. p. 45.

Ojeda, R. (2008). Socialización de procesos de innovación para el desarrollo municipal. Centro de Estudios de Desarrollo Agrario y Rural. Habana. p. 50.

ONU. (2014). Políticas agroambientales. Análisis de casos de Brasil, Chile, Colombia, México y Nicaragua. Oficina Regional de la FAO para América Latina y el Caribe. Santiago de Chile.

ONU. (2015). Agenda 2030. Objetivos de Desarrollo Sostenible. Proyecto de documento final de la Cumbre de las Naciones Unidas. [Consultadojulio2020].

Osorio, A. (2012). Estrategia pedagógica para el mejoramiento del desempeño profesional pedagógico en la educación del valor responsabilidad ambiental en los profesores de secundaria básica. 2012._116, [50] h. (Tesis de Doctorado). UCP —Enrique J. Varonall, La Habana

Pérez, M., \& others. (2012). Diccionario de términos geográficos. Editorial Pueblo y Educación, Cuba Periódico Granma. (2017). Plan del Estado para el Enfrentamiento al Cambio Climático (Tarea Vida). La Habana: Editorial Política.

Rigby, D., \& Cáceres, D., (2001). Organic farming and the sustainability of agricultural systems. In Agricultural Systems, (68).

Roque Molina, M.G. (2003). Estrategia Educativa para la Formación de la Cultura Ambiental de los profesionales cubanos de nivel superior orientado al desarrollo sostenible (Tesis de Doctorado). Universidad de Ciencias Pedagógicas, La Habana.

Sammarco, Y.M. (2014). Educación ambiental y paisajes para la gestión participativa de las áreas protegidas en Brasil (Tesis de doctorado), Universidad Autónoma de Madrid, España.

Santos Abreu, I. (2002). Estrategia de formación continuada en educación ambiental para docentes (Tesis de Doctorado). Universidad de Ciencias Pedagógicas, Cuba.

Suárez Lorenzo, A., Chávez Rodríguez, J., \& Permuy González, L. (2005). Acercamiento necesario a la Pedagogía general (p.72). Playa, Cuba: Editorial Pueblo y Educación

Valdés, A.C. (2019). La Educación Ambiental y su carácter interdisciplinario en el proceso de enseñanza-aprendizaje. CD Memorias del I Taller Nacional de Didáctica (Curso Pre-evento), (CD-ROM).

Valdés, O. (1995). La educación ambiental Para el Desarrollo Sostenible en las Montañas de Cuba. La Habana, Editorial, Pueblo y Educación

Valdés, O. (1996). La educación ambiental en el proceso docente educativo en las montañas de Cuba. [Tesis presentada en opción al Grado Científico Doctor en Ciencias Pedagógicas]. La Habana, Cuba: Instituto Central de Ciencias Pedagógicas

Valdés, O., Rodríguez, M., Llivina, M., \& Merino, T. (2012). La evaluación de la educación ambiental desde una concepción teórico-práctica interdisciplinaria e integradora en los programas y proyectos educativos institucionales en Cuba. En Memorias del XII Congreso Internacional de Didáctica de las Ciencias. La Habana.

Varela, M. (2016). Educación ambiental para la sostenibilidad en la formación inicial de profesorado de educación infantil y primaria (Tesis de doctorado) Universidad de Vigo. España. 